\title{
Evaluation of a Moving-Bed System for Hot-Gas Cleanup
}

R. H. Lamb

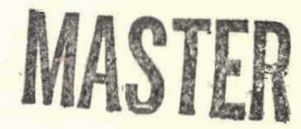

OAK RIDGE NATIONAL LABORATORY OPERATED BY UNION CARBIDE CORPORATION - FOR THE DEPARTMENT OF ENERGY 


\section{DISCLAIMER}

This report was prepared as an account of work sponsored by an agency of the United States Government. Neither the United States Government nor any agency Thereof, nor any of their employees, makes any warranty, express or implied, or assumes any legal liability or responsibility for the accuracy, completeness, or usefulness of any information, apparatus, product, or process disclosed, or represents that its use would not infringe privately owned rights. Reference herein to any specific commercial product, process, or service by trade name, trademark, manufacturer, or otherwise does not necessarily constitute or imply its endorsement, recommendation, or favoring by the United States Government or any agency thereof. The views and opinions of authors expressed herein do not necessarily state or reflect those of the United States Government or any agency thereof. 


\section{DISCLAIMER}

Portions of this document may be illegible in electronic image products. Images are produced from the best available original document. 


\section{Printed in the United States of America. Available from Natlonal I echnical Information Service \\ U.S. Department of Commerce 5285 Port Royal Road, Springfield, Virginia 22161 \\ Price: Printed Copy $\$ 4.50$; Microfiche $\$ 3.00$}

This report was prepared as an account of work sponsored by an agency of the United States Government. Neither the United States Government nor any agency thereof, nor any of their employees, contractors, subcontractors, or their employees, makes any warranty, express or implied, nor assumes any legal liability or responsibility for any third party's use or the results of such use of any information, apparatus, product or process disclosed in this report, nor represents that its use by such third party would not infringe privately owned rights. 
Contract No. W-7405-eng-26

CHEMICAL TECHNOLOGY DIVISION

EVALUATION OF A MOVING-BED SYSTEM FOR HOT-GAS CLEANUP

R. H. Lamb*

and Staff of the Engineering Coordination and Analysis Section, Chemical Technology Division

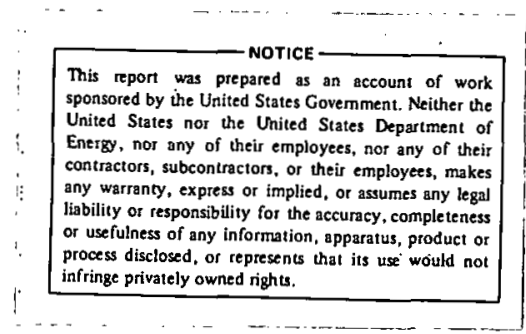

*Consultant; present address: Alcoa, Tennessee

Date Puhlished: June 1978

NOTICE This document contains information of a preliminary nature. It is subject to revision or correction and therefore does not represent a final report.

OAK RIDGE NATIONAL LABORATORY

Oak Ridge, Tennessee 37830

operated by

UNION CARBIDE CORPORATION

for the

DEPARTMENT OF ENERGY 


\section{THIS PAGE}

\section{WAS INTENTIONALLY \\ LEFT.BLANK}


ABSTRACT ............................ . . . . 1

1. INTRODUCTION . . . . . . . . . . . . . . . . 2

2. TASK PROCEDURE .................... . . 2

3. Conclustons. . . . . . . . . . . . . . . . 3

3.1 Sulfur Removal . .. . . . . . . . . . . . . 3

3.2 Particulate Removal .............. 4

4. RECOMMENDATIONS ... . . . . . . . . . . . . 5

5. FLOWSHEET DESCRIPTION . . . . . . . . . . . . . . 5

5.1 Reference System (Fig. 1) . . . . . . . . . . 10

5.2 Moving-Bed System (Fig. 2) . . . . . ...... 14

6. FLOWSHEET ALTERNATIVES . . • . . . . . . . . . . . . 16

6.1 Fixed-Bed System (Fig. 1) . . . . . . . . . . . 17

6.2 Moving-Bed System (Fig. 2) . . . . . . .... 17

7. ECONOMIC EVALUATION . . . . . . . . . . . . . . ${ }^{3} 18$

7.1 Capital Cost Differentials . . . . . . . . . 18

7.2 Operating Cost Differentials . . . . . . . . . 18

7.3 Comparison of Estimated Costs.......... . 20

8. REFERENCES . . . . . . . . . . . . . . . . . . 21 
EVALUATION OF A MOVING-BED SYSTEM FOR HOT-GAS CLEANUP

\author{
R. H. Lamb \\ and the \\ Staff of the Engineering Coordination and Analysis Section
}

\title{
ABSTRACT
}

A study was conducted of the feasibility of passing hot, raw gasifier gas from coal conversion through a proposed, regenerable moving bed of particles for removal of sulfur and particulates from the gas. A more conventional system using a regenerable, fixed bed of particles for sulfur removal and a panel filter for dust removal was selected from the open literature and used as the reference system for determining the merits of the proposed moving-bed system.

The composition and quantity of raw gas used for cost evaluation in the reference study of hot-gas cleanup were based on gasifying $1 \mathrm{MM}^{*} \mathrm{lb} / \mathrm{hr}$ of $\mathrm{MAF}$ coal. Further, for the oxygen-blown Lurgi case in the reference study, eight parallel trains of fixed-bed, hot-gas cleanup equipment were provided for sulfur sorption. In the present study, the moving-bed system was evaluated on the same basis, with the following results:

- The fixed capital investment for the moving-bed system is estimated to be $\$ 24,000,000$ (or $231 \%$ ) less than that for the fixed-bed system.

- Both systems recover more energy (as highpressure steam) than they consume. The moving-bed system recovers $120 \mathrm{MM} \mathrm{Btu/hr}$ ( $292 \%$ ) more energy for export than the reference system.

- The plant level cost of owning and operating the facilities (excluding sorbent inakeup cost) is estimated to be $\$ 8,100,000(248 \%)$ per year less for the moving-bed system.

- Nesign of the moving-bed systeil required a total sorbent recycle rate of $372,000 \mathrm{lb} / \mathrm{hr}$. The cycle time is $3.5 \mathrm{hr}$, and about 2300 cycles are required in an 8000-hr operating year. At the break-even point, the amount of makeup sorbent that can be afforded per cycle at a nominal unit sorbent cost of $\$ 0.50 / \mathrm{lb}$ amounts to $8400.1 \mathrm{~b}$ or $0.65 \%$.

*In this report, $M=10^{3} ; M M=10^{6}$. 


\section{INTRODUCTION}

Raw gas produced by coal gasifiers contains dust and sulfur compounds that must be removed to provide an adequately clean synthesis or fuel gas stream. Methods currently employed for sulfur removal and high-efficiency dust recovery require relatively low operating temperatures. Since the hot, raw gas must be cooled with some heat unrecovered, the thermal efficlency of the gasificalion sys̄tem is teduced.

A number of methods for recovering dust and removing sulfur compounds from raw gas at high temperature are at early investigative stages at various institutions. The objective of this investigation was to evaluate the proposed moving-bed system for removal of sulfur and particulates from raw gasifier gas and to determine, in a preliminary fashinn, the potential of the system for improved thermal efficiency and process economics as compared with a more conventional approach.

\section{TASK PROCEDURE}

Iron oxide was selected as a promising regenerable sulfur sorbent to be one component of the moving-bed particles for the present study on the basis of a literature review. A flxed=bed procegs uning iron oxide and fly ash for sulfur removal from liot gases has also been evaluated $^{1}$. by comparison with conventional cold gas processes, and results indicate that hot-gas sulfur removal would be competitive and would offer improved economy for cleuning gases produced in oxygenblown Lurgi generators used in combined-cycle power systems. The 
fixed-bed sulfur removal process was used for comparison in the present evaluation of the moving-bed process.

Process calculations were made ${ }^{2-4}$ and comparable flowsheets were prepared for each system. Differences in capital costs and utility requirements were estimated. Operating cost estimates were prepared to determine the amount of sorbent attrition that can be afforded at various sorbent unit costs. All process information used in preparing the designs was obtained from published reports and technical references.

\section{CONCLUSIONS}

\subsection{Sulfur Removal}

The present preliminary evaluation suggests that a suitable sorbent would allow the moving-bed system to operate below the break-even point relative to makeup requirements and, hence, to be competitive with fixed-bcd systems lypilled by those considered for cleanup of oxygenblown Lurgi generatur off-gases. At a sorbent cost of $50 \mathrm{c}$ per $1 \mathrm{~b}$, the break-even sorbent makeup rate is estimated to be $0.65 \%$ per cycle. The cost and makeup rate noted, while nominal, are clearly in the range of feasibility.

The fixed-bed ${ }^{1}$ system is cyclic, and the percentage of sulfur removed from the raw gas stream varies during the cycle. Essentially complete removal takes place during the first part and falls off rapidly toward the end of a cycle. The fixed-bed design is based on an average $95 \%$ efficiency. In the moving-bed absorber, ${ }^{*}$ contact between the gas * This report uses the common commercial terms absorption and absorber instead of adsorption and adsorber to denote gas sorption by a solid sorbent. 
and sorbent is in a cross-flow pattern. Essentially complete absorption takes place near the top, where the sorbent is fresh, and falls of near the bottom where much of the sorbent is spent. The present study assumes that the moving-bed absorber will achieve an average sulfur removal efficiency equal to that of the fixed-bed reference system. Applicable kinetic data required for calculating the efficiency are not availablc.

\subsection{Particulare Remova1}

The panel filter in the reference system must have high dust removal efficiency to enable the sorbent beds to operate for extended periods without plugging. The filter selected for the present study is similar to the $13-\mathrm{ft}-\mathrm{OD}$ unit built by the Combustion Power Company ${ }^{5}$ to clean up fluid-bed combustor gas for use in a gas turbine. The test program has not been carried out due to a mechanical failure in the filter during shakedown, and the program has been transferred to Morgantown Energy Research Center (MEKL) for small-scale development work. The MERC program includes a 3-ft-ID unit designed for operation at $1200^{\circ} \mathrm{F}$ and $15 \mathrm{psig}$. The test program has not been initiated.

With respect to removal of particulates that enter with the gas stream, the efficiency of the moving-bed absorber should be comparable to that of the panel filter. However, the subject iron oxide/silica sorbent is reported ${ }^{1,6}$ to be more friable than the alumina medium indicated for the panel filter. It is possible that off-gas from the moving-bed system would have a higher dust content than off-gas from the reference system due to sorbent attrition. ${ }^{7}$ Quantitative information 
on attrition of the sorbent under proposed operating conditions is not available.

\section{RECOMMENDATIONS}

The present evaluation should be reviewed with sorbent developers, with particular emphasis on problems and perspectives beyond its scope. In addition, the evaluation should be reviewed with personnel at Energy Research Centers (e.g., MERC) who have been involved in programs concerned with comparable panel filters and with hot-gas cleanup systems using iron oxide. If a positive consensus is reached, future experimental work would include (1) obtaining kinetic data for absorption and regeneration of selected sorbents, (2) conducting fluid-bed and other attrition tests (the computer program written by IGT for investigation of fluid-bed attrition in connection with the steam-iron process [under ERDA Contract No. E(49-18)-1518] may be of interest), and (3) building and operating an experimental moving-bed system for hot-gas cleanup.

\section{FLOWSHEET DESCRIPTTON}

Figures 1 and 2 are flowsheets for the reference and moving-bed systems for hot-gas cleanup. All major equipment items are shown, and a brief description of each is given at the top of each flowsheet. The number of parallel units required to meet capacity, flow rates for total plant capacity, and physical conditions of selected process streams are also given. Chemical compositions of the streams are given in Tables 1 and 2. Normal operation of each of the systems is described below. 
ORNL DWG 77-2248R

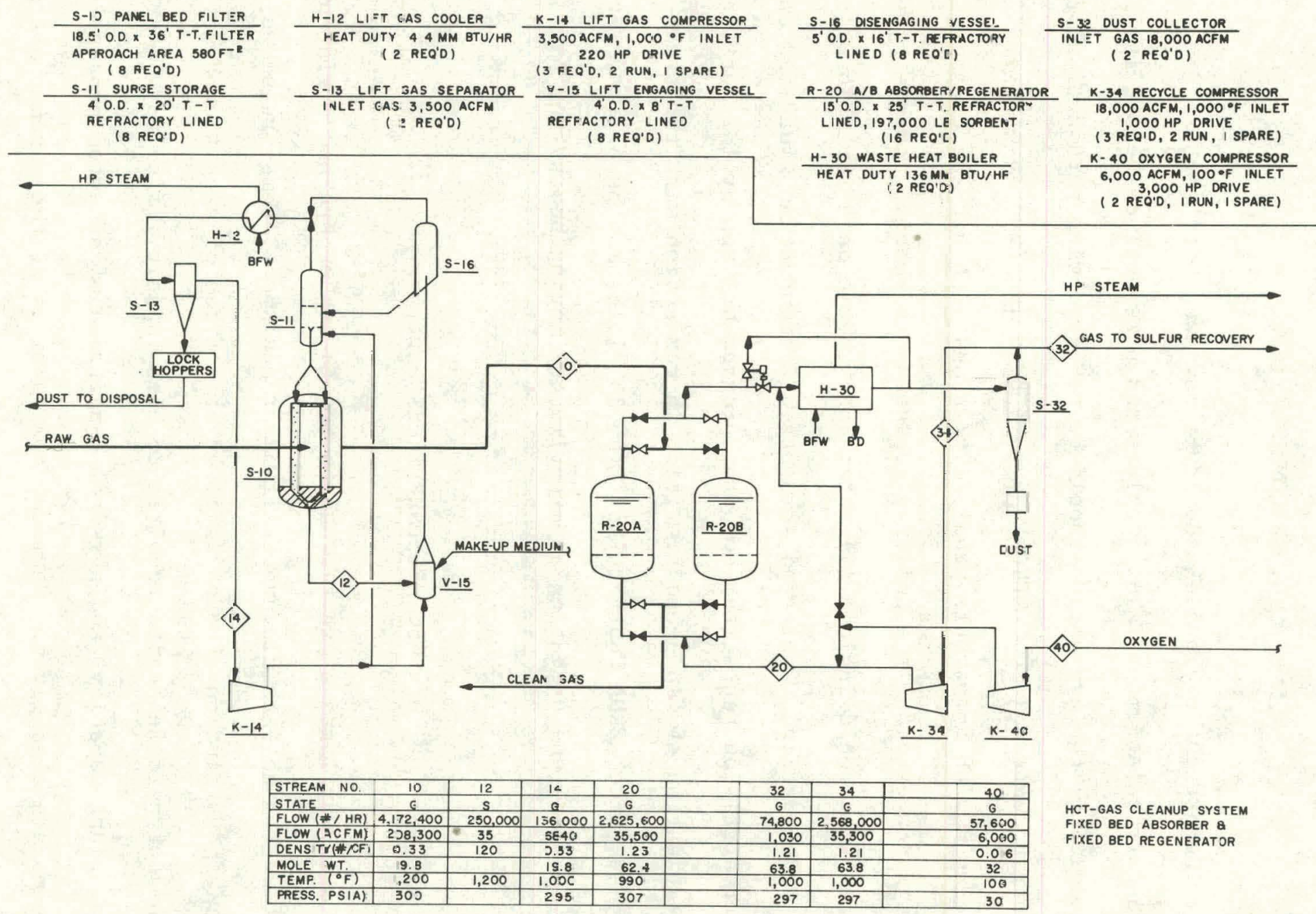

Fig. 1. Fixed-bed system flowsheet. 
ORNL DWG 77-2249

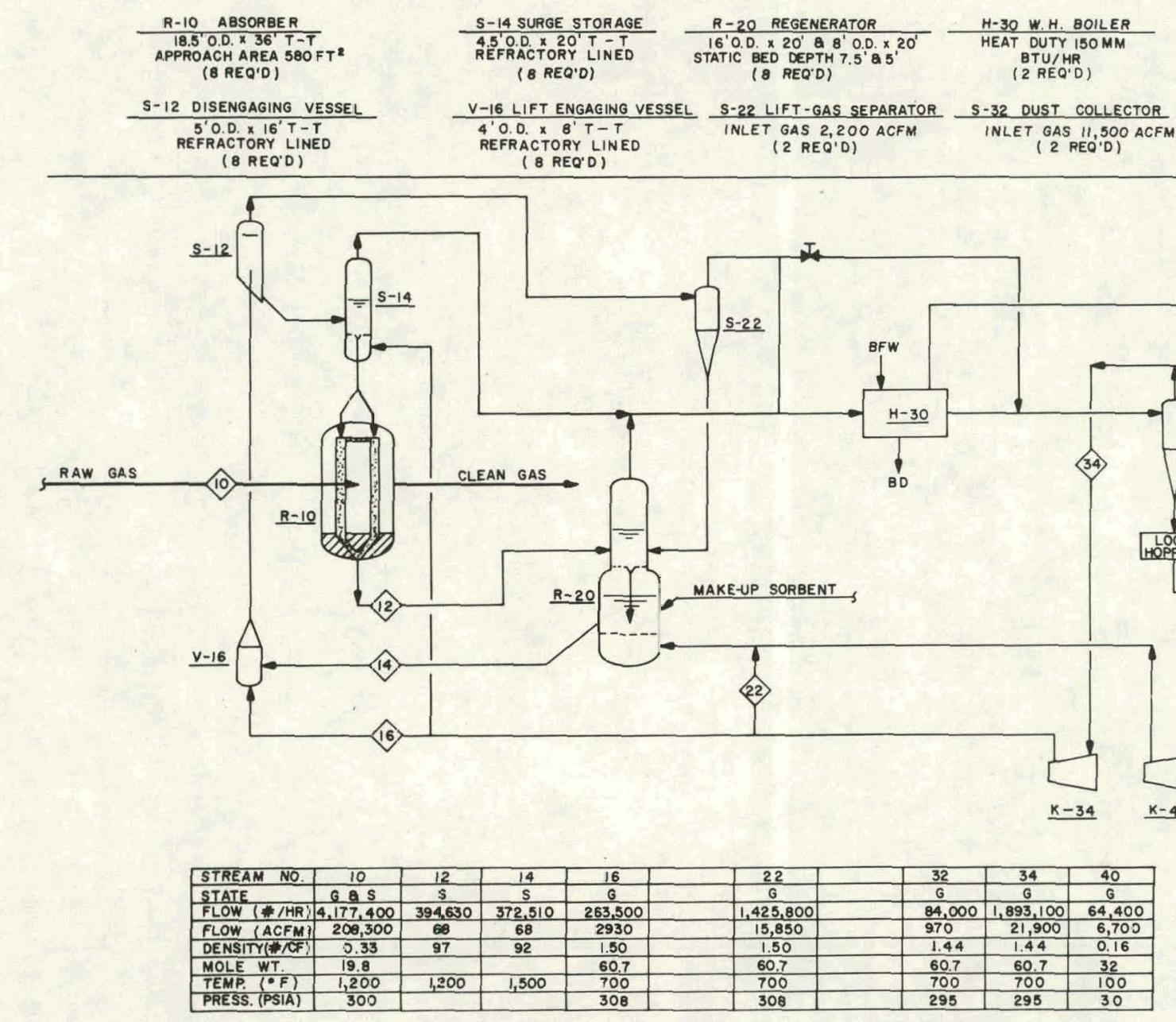

$\frac{K-34 \text { RECYCLE } \text { COMPRESSOR }}{11,000 \text { ACFM, } 1,000^{\circ} \text { F INLET }}$

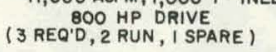

K-40 OXYGEN COMPRESSOR 6,700 ACFM, $100^{\circ} F$ INLET
$3,400 \mathrm{HP}$ ORIVE ( 2 REQ'D, I RUN, I SPARE)

HOT-GAS CLEANUP SYSTEM MLVING BED ABSORBER \&

Fig. 2. Moving-bed system flowsheet. 
Table 1. Composition of streams shown in Fig. 1

\begin{tabular}{|c|c|c|c|c|c|c|c|}
\hline \multicolumn{8}{|c|}{ Stream number (state) } \\
\hline & $\begin{array}{c}10(\mathrm{~g}) \\
(\operatorname{mole} \%)\end{array}$ & $\begin{array}{l}12(s) \\
\text { (wt \%) }\end{array}$ & $\begin{array}{c}14(\mathrm{~g}) \\
(\operatorname{mole} \%)\end{array}$ & $\begin{array}{c}20(\mathrm{~g}) \\
(\operatorname{mole} \%)\end{array}$ & $\begin{array}{c}32(g) \\
(m o=e \%)\end{array}$ & $\begin{array}{c}34(\mathrm{~g}) \\
(\mathrm{mole} \%)\end{array}$ & $\begin{array}{c}40(\mathrm{~g}) \\
(\operatorname{mole} \%)\end{array}$ \\
\hline \multicolumn{8}{|l|}{ Components } \\
\hline $\mathrm{H}_{2}$ & 20.86 & & 20.86 & & & & \\
\hline CO & 7.47 & & 7.47 & & & & \\
\hline $\mathrm{CO}_{2}$ & 15.24 & & 15.24 & & & & \\
\hline $\mathrm{C}_{x} \mathrm{H}_{\mathrm{y}}$ & 4.90 & & 4.90 & & & & \\
\hline $\mathrm{H}_{2} \mathrm{~S}+\mathrm{COS}$ & 0.61 & & 0.61 & & & & \\
\hline $\mathrm{N}_{2}+\mathrm{NH}_{3}$ & 0.58 & & 0.58 & & & & \\
\hline $\mathrm{H}_{2} \mathrm{O}$ & 50.34 & & 50.34 & & & & \\
\hline $\mathrm{Al}_{2} \mathrm{O}_{3}$ & & 35.0 & & & & & \\
\hline $\mathrm{SiO}_{2}$ & & 15.0 & & & & & \\
\hline $\mathrm{O}_{2}$ & & & & 5.1 & 0.35 & 0.85 & 100.0 \\
\hline $\mathrm{SO}_{2}$ & & & & 94.9 & 99.15 & 99.15 & \\
\hline Total & 100.00 & 100.0 & 100.00 & 100.0 & 100.00 & 100.00 & 100.0 \\
\hline
\end{tabular}


Table 2. Composition of streams shown in Fig. 2

\begin{tabular}{|c|c|c|c|c|c|c|c|c|c|}
\hline & \multicolumn{9}{|c|}{ Stream number (state) } \\
\hline & $\begin{array}{c}10(g) \\
(\text { mole \%) }\end{array}$ & $\begin{array}{r}10(s) \\
(w t \%)\end{array}$ & $\begin{array}{l}12(\mathrm{~s}) \\
(\text { wt } \%)\end{array}$ & $\begin{array}{r}14(s) \\
\text { (wt \%) }\end{array}$ & $\begin{array}{c}16(\mathrm{~g}) \\
\text { (mole \%) }\end{array}$ & $\begin{array}{c}22(\mathrm{~g}) \\
\text { (mole } \%)\end{array}$ & $\begin{array}{c}32(\mathrm{~g}) \\
(\operatorname{mole} \%)\end{array}$ & $\begin{array}{c}34(\mathrm{~g}) \\
(\operatorname{mole} \%)\end{array}$ & $\begin{array}{c}40(\mathrm{~g}) \\
(\operatorname{mole} \%)\end{array}$ \\
\hline \multicolumn{10}{|l|}{ Components } \\
\hline $\mathrm{H}_{2}$ & 20.86 & & & & & & & & \\
\hline $\mathrm{CO}$ & 7.47 & & & & & & & & \\
\hline $\mathrm{CO}_{2}$ & 15.24 & & & & 15.03 & 15.03 & .15 .03 & 15.03 & \\
\hline $\mathrm{C}_{x} \mathrm{H}_{\mathrm{y}}$ & 4.90 & & & & & & & & \\
\hline $\mathrm{H}_{2} \mathrm{~S}+\mathrm{COS}$ & 0.61 & & & & & & & & \\
\hline $\mathrm{N}_{2}+\mathrm{NH}_{3}$ & 0.58 & & & & & & & & \\
\hline $\mathrm{H}_{2} \mathrm{O}$ & 50.34 & & & & & & & & \\
\hline C & . & 50.0 & 0.63 & & & & & & \\
\hline Ash & & 50.0 & 0.63 & & & & & & \\
\hline $\mathrm{Fe}_{2} \mathrm{O}_{3}$ & & & & 20.71 & & & & & \\
\hline $\mathrm{FeO}$ & & & 5.32 & 1.93 & & & & & \\
\hline $\mathrm{FeS}$ & & & 2.23 & 2.36 & & & & & \\
\hline $\mathrm{Fe}_{2} \mathrm{~S}_{3}$ & & & 20.39 & & & & & & \\
\hline $\mathrm{SiO}_{2}$ & & & 70.80 & 75.00 & & & & & \\
\hline $\mathrm{O}_{2}$ & & & & & 1.01 & 1.01 & 1.01 & 1.01 & 100.00 \\
\hline $\mathrm{SO}_{2}$ & & & & & 83.96 & 83.96 & 83.96 & 83.96 & \\
\hline Tot $\approx 1$ & 100.00 & 100.00 & 100.00 & 100.00 & 100.00 & 100.00 & 100.00 & 100.00 & 100.00 \\
\hline
\end{tabular}




\subsection{Reference System (Fig. 1)}

\section{$\underline{5.1 .1}$ Dust remova1}

Dust, which can cause plugging in the fixed-bed absorbers, must be efficiently removed from the raw gas stream. A panel filter of the type being developed by the Combusion Power Company ${ }^{8}$ was selected for use in the present evaluation. The filter $(S-10)$ consists of two concentric, louvered cylinders installed in a vertical, cylindrical pressure she11. The annular space between the louvered cylinders is filled with a high-alumina medium in the form of 8- to 12-mesh (0.07-in.-diam) spherical granules. Raw gas enters the inner cylinder and flows radially out through the annular bed, which is about 20 in. thick. Dust particles are trapped in the media voids, and particulatefree gas is piped to the sulfur absorbers.

The filter medium and dust are continuously withdrawn from the bottom of the filter and elevated by gas lift to the disengaging vessel (s-16). The medium part1cles settle and flow by gravity to the fluidized surge storage vessel (S-11). Most of the dust collected by the filter, along with fines produced by attrition of the medium, are carried out of the disengaging vessel as entrainment in the gas stream. The surge storage equipment is designed for elutriation of

any remaining dust before the medfum ls zecycled to the filter. Makeup medium is added as necessary to maintain a level in the surge storage vesse1.

Gas and dust from the surge storage and disengaging vessels join and flow through the lift gas cooler ( $\mathrm{H}-12)$, where heat is removed by 
generation of high-pressure steam. The stream is cooled to protect the lift gas compressor (K-14) from excessive temperature. The cooler outlet stream passes through the lift gas separator (S-13), where essentially all of the dust brought in by the raw gas, or formed by medium attrition, is removed from the system through lock hoppers. The lift gas compressor is a booster type with very low compression ratio, and its dust tolerance is relatively high. However, the lift gas separator requires at least two stages of cyclones for protection of the compressor.

\section{$\underline{5.1 .2 \text { Absorption }}$}

The sulfur sorption and regeneration system used for this evaluation is essentially the same as the one used in the EPRI evaluation prepared by Stone \& Webster Engineering Corporation. ${ }^{1}$ The absorption/regeneration vessel has an I.D. of $13.5 \mathrm{ft}$ inside the refractory lining with a $15-\mathrm{ft}-$ deep bed of sorbent supported on a grid.. Fresh sorbent consists of $25 \% \mathrm{Fe}_{2} \mathrm{O}_{3}$ and $75 \% \mathrm{SiO}_{2}$ by weight, and the particles, formed by extrusion, are $1 / 4$ in. diam and about $1 / 2$ in. long. The design sulfur pickup leve1 is 10 wt \%. The absorption and regeneration phases of the operating cycle are each of $4 \mathrm{hr}$ duration.

At the start of the absorption cycle, the bed is in a freshly regenerated state. Most of the bed is at the temperature of the inlet regenerating gas $\left(1000^{\circ} \mathrm{F}\right)$, and most of the iron in the bed is in the completely oxidized state $\left(\mathrm{Fe}_{2} \mathrm{O}_{3}\right)$. Major reactions during the absorption phase are represented as follows: 


$$
\begin{aligned}
& \mathrm{Fe}_{2} \mathrm{O}_{3}+\mathrm{H}_{2}(\text { or } \mathrm{CO}) \rightarrow 2 \mathrm{FeO}+\mathrm{H}_{2} \mathrm{O}\left(\text { or } \mathrm{CO}_{2}\right), \\
& \mathrm{FeO}+\mathrm{H}_{2} \mathrm{~S} \rightarrow \mathrm{FeS}+\mathrm{H}_{2} \mathrm{O} \\
& \mathrm{FeS}+\mathrm{H}_{2} \mathrm{~S} \rightarrow \mathrm{FeS}_{2}+\mathrm{H}_{2} .
\end{aligned}
$$

The first reaction is endothermic and the last two are exothermic. Calculations indicate that the net heat release will just about balance heat losses. During most of the absorption period, the temperatures of inlet and outlet gas will be about the same. If the inlet gas is not in equilibrium with respect to the shift reaction, the sorbent reportedly ${ }^{9}$ will act as a shift catalyst.

At the finish of the absorption cycle, the bed is at the temperature of the inlet gas $\left(1200^{\circ} \mathrm{F}\right)$, and most of the iron is in a sulfided state with an approximate iron-to-sulfur ratio as indicated by the formula $\mathrm{Fe}_{2} \mathrm{~S}_{3}$. During absorption, the bed experiences a temperature change from $1000^{\circ} \mathrm{F}$ to $1200^{\circ} \mathrm{F}$, and most of the iron shanges from $\mathrm{Fe}_{2} \mathrm{O}_{3}$ to the equivalent $\mathrm{Fe}_{2} \mathrm{~S}_{3}$.

\section{$\underline{5.1 .3 \text { Regeneration }}$}

Major reactions during regeneration are represented by

$$
\begin{aligned}
& 2 \mathrm{Fe}_{2} \mathrm{~S}_{3}+9 \mathrm{O}_{2} \rightarrow 2 \mathrm{Fe}_{2} \mathrm{O}_{3}+6 \mathrm{SO}_{2}, \\
& 4 \mathrm{FeO}+\mathrm{O}_{2} \rightarrow 2 \mathrm{Fe}_{2} \mathrm{O}_{3} .
\end{aligned}
$$

Both reactions are strongly exothermic; and heat removal is necessary to prevent fusion of the sorbent. The heat removal method used for this evaluation is by recycling a stream of relatively cool $\mathrm{SO}_{2}$, which is the same method that was used in the EPRI evaluation. 1

Oxygen for regeneration enters the regenerator $(\mathrm{R}-20 \mathrm{~B})$ in stream No. 20 , which contains enough recycled $\mathrm{SO}_{2}$ to limit the outlet gas temperature to about $1500^{\circ} \mathrm{F}$. The outlet gas is cooled to $1000^{\circ} \mathrm{F}$ in 
a waste heat boiler $(\mathrm{H}-30)$, and any particulates that might damage the recycle compressor $(\mathrm{K}-34)$ are removed by the dust collector (S-32). The regeneration off-gas is piped to a sulfur recovery facility, and the remainder is recirculated.

Formation of elemental sulfur by reaction of $\mathrm{SO}_{2}$ with iron sulfide is possible but conditions are not favorable. ${ }^{1,10}$ The reaction is not possible in the presence of oxygen; however, early in the regeneration cycle, oxygen is completely consumed and the outlet gas could contain a low concentration of sulfur vapor. This is not undesirable if the concentration is not high enough to cause condensation of sulfur on the boiler tubes or excessive heating of regenerator inlet gas due to sulfur combustion. On the flowsheet, an oxygen connection is shown at the entrance to the waste heat boiler to provide for combustion of elemental sulfur in the boiler if necessary.

The temperature $\left(1000^{\circ} \mathrm{F}\right)$ selected for the recycle gas is a compromise. A higher temperature would increase the capacity and design temperature requirements of the recycle compressor. A lower temperature would decrease these requirements but would result in wider temperature swings in the sorbent bed and a lower bed temperature at the start of an absorption period. The EPRI report specifies a lower limit on the absorption operating temperature of $1000^{\circ} \mathrm{F}$ to avoid problems resulting from tar condensation. Air Products and Chemicals, Inc., conducted sorbent tests at various temperatures and concluded ${ }^{11}$ that an absorber should not be operated at temperatures near $900^{\circ} \mathrm{F}$ because of sorbent crumbling. However, operation at lower and higher temperatures is satisfactory. A bypass around the waste heat boiler is shown on the flowsheet for control of recycle gas temperature. 


\subsection{Moving-Bed System (Fig. 2)}

The description of the fixed-bed flowsheet should be read first because it is referred to in the moving-bed flowsheet description.

\section{$\underline{5.2 .1 \quad \text { Absorption }}$}

The sorbent in the moving-bed system is the same as that in the fixed-bed reference system except that the particles are spherical, with a size range from 6 to 20 mesh. The absorber (R- $1 U$ ) design is identical to the panel-bed filter described in Sect. 5.1. Raw gas enters the inner cylinder and flows radially out through the annular bed, which is about 20 in. thick. Dust particles are trapped in the sorbent voids, and $\mathrm{H}_{2} \mathrm{~S}$ is removed by reaction with the sorbent. The reactions are the same as described in Sect. 5.1. Since the net reaction heat is small, only minor temperature changes take place in the absorber.

Sorbent and dust are continuously withdrawn from the bottom of the absorber and fed into the regenerator. Regenerated absorbent is returned via stream No. 14 and is elevated by a gas lift to the disengaging vesse1 (S-12). Most of the sorbent separates from the gas and flows by gravity to the fluidized surge storage vessel (S-14). Sorbent that remains in the exit gas stream is recovered by the lift gas separator $(\varepsilon-22)$ and recurned to the regenerator. The surge storage installation is designed for elutriation of minus-20 mesh particles before the sorbent enters the absorber. Lift gas and gas for fluidizing the surge storage vessel are supplied as a side stream from the regeneration system recycle compressor. 


\section{$\underline{5.2 .2 \quad \text { Regeneration }}$}

Regeneration is carried but continuously in a two-stage fluid-bed regenerator $(R-20)$. Sorbent and dust enter the top bed where dust and minus-20 mesh particles are elutriated. The remaining sorbent flows by gravity to the lower bed, where nearly all of the regeneration takes place, and is then recycled to the absorber. Makeup sorbent is added as necessary to keep a constant inventory in the system.

A mixture of recycle gas and oxygen flows upward through the two beds in series. The regeneration reactions are described in Sect. 5.1. An additional reaction that takes place in the top bed is oxidation of carbon in the dust to form $\mathrm{CO}_{2}$. Outlet gas from the regenerator at $1500^{\circ} \mathrm{F}$, together with $1100^{\circ} \mathrm{F}$ gas from the surge storage vessel and $1200^{\circ} \mathrm{F}$ gas from the lift gas separator, flows through the waste heat boiler $(\mathrm{H}-20)$ which cools the stream to $700^{\circ} \mathrm{F}$. Dust is separated from the gas stream by the dust collector $(S-32)$ and is removed from the system through lock hoppers. Part of the outlet gas is piped to a sulfur recovery facility, and the remainder is recirculated by recyc1e compressor $(K-32)$.

The sizes of the fluid beds and the temperature and flow rate of the inlet recycle gas stream are determined by conditions assumed or selected for operation of the beds. The conditions may require revision as kinetic data applicable to the proposed operating parameters become available. The conditions selected for the present study are: 


$\begin{array}{lccc} & \text { Lower Bed } & \text { Upper Bed } \\ \text { Operating temperature, }{ }^{\circ} \mathrm{F} & 1500 & 1500 \\ \text { Gas superficial velocity, fps } & 1.5 & 8 \\ \text { Sorbent retention time, min } & 20 & \\ \text { Bed height/diameter ratio } & 0.5 & \end{array}$

The uperating comperature of the beds is controlled by a bypass around the waste heat boiler which controls the recycle gao tcmperature. On the flnwshept, all oxygen for regenelallull is shnwin entoring the lower bed. If required to balance the bed temperatures or to suppress elemental sulfur formation, some of the oxygen can be added at other points in the regenerator.

\section{FLOWSHEET AI.TERNATIVES}

Air, or oxygen-enriched air, can be used instead of oxygen for regeneration in either system. Tf air is used, it will requile compression to system pressure, and the $\mathrm{SO}_{2}$ stream to sulfur recovery will be diluted with nitrogen. Purges will likely be required in either system to minimize contamination of gasifier gas with regeneration gas and vice versa. A recycled oxygen-depleted stream can be used for this purpose.

By using a Claus process equivalent in place of purely oxidative regeneration of the iron oxide sorbent, the process economics for the moving-bed system could be improved. Ilowever, this approach, if successfully developed, could also be applied to the fixed-bed system. Theoretical equilibrium studies conducted by MERC ${ }^{12}$ suggest the 
possibility of limiting the amount of oxygen fed to the regenerator to produce a mixture of $\mathrm{SO}_{2}$ and $\mathrm{S}_{2}$ vapor, but experimental verification of these projections is needed. The EPRI evaluation ${ }^{1}$ alludes to the need for experimental support, without which the subject alternative cannot be claimed to be feasible, and to mechanical and materials problems that may render the idea impractical.

\subsection{Fixed-Bed System (Fig. 1)}

1. The lift gas cooler is shown ahead of the lift gas separator. The cooler can be located after the separator or between stages of separation.

2. The lift gas has the same composition as the gasifier gas, which has a high water-vapor partial pressure and a high dew point. The water vapor in the gas lift loop can be reduced by adding a small purge stream of relatively dry gas at some point in the loop.

\subsection{Moving-Bed System (Fig. 2)}

1. A moving-bed unit similar to the absorber could possibly be used as a regenerator, but the capital investment would be higher than for fluidized regeneration.

2. The waste heat boiler is shown ahead of the dust collector. The boiler can be located after the separator or between stages of separation. 
3. As shown on the flowsheet, all cooling is handled by the waste heat boiler $(\mathrm{H}-30)$. Calculations indicate that this arrangement is best when the system pressure is above about 15 atm. At lower pressures, it appears that an arrangement with some cooling by use of steam-generating coils in the regenerator would be more attractive.

\section{ECONOMIC EVALUATION}

\subsection{Capital. Cost Differentials}

Differences in costs were estimated for equipment shown in Pigs. 1 and 2. Differential direct costs for equipment modular installations were then estimated by conventional methods. ${ }^{13}$ Estimated increased capital costs for the fixed-bed reference system over the moving-bed system are:

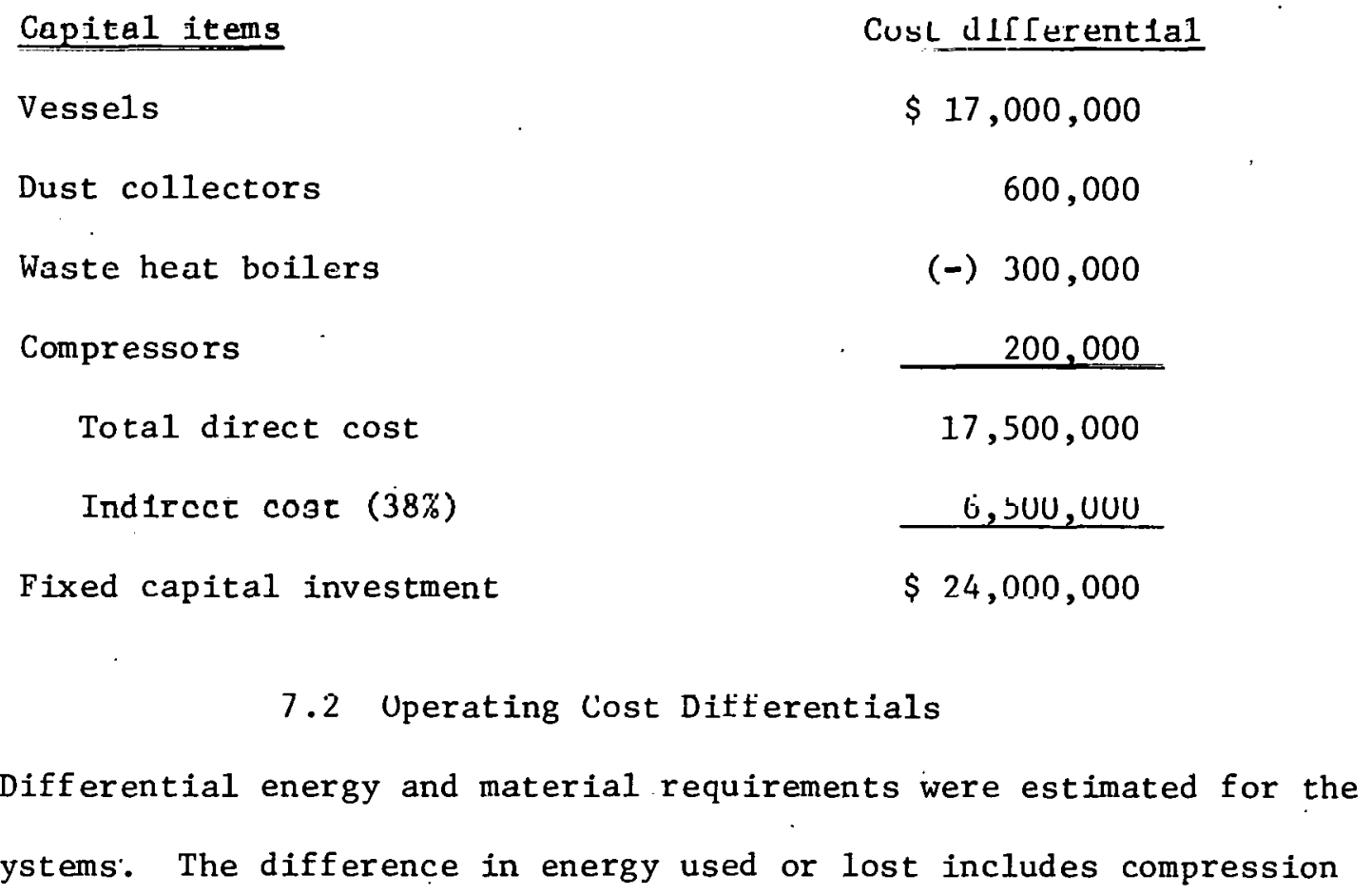


power, waste heat recovery, and gasifier gas pressure loss in passing. through the absorbers. The energy, expressed in equivalent heat units, amounts to $120 \mathrm{MM} \mathrm{Btu} / \mathrm{hr}$ in favor of the moving-bed system. Assuming that the filter medium for the reference system requires replacement annually, additional requirements for this system during an $8000-\mathrm{hr}$ operating year are:

Energy

Filter medium

$$
960,000 \text { MM Btu }
$$$$
1,400,0001 \mathrm{~b}
$$

Assuming an energy value of $\$ 2$ per MM Btu and medium cost at $50 €$ per pound, the following differential manufacturing costs, excluding the cost of sorbent consumed, are estimated as follows:

\begin{tabular}{|c|c|}
\hline Manufacturing items & $\begin{array}{c}\text { Cost differential } \\
\text { per year }\end{array}$ \\
\hline Energy & $\$ 1,920,000$ \\
\hline Medium & 700,000 \\
\hline Maintenance ( $4.5 \%$ of capital) & $1,080,000$ \\
\hline Differential direct expense & $3,700,000$ \\
\hline G\&A expense ( $20 \%$ of maintenance) & 200,000 \\
\hline Taxes and Insurance ( $2.5 \%$ of cap1tal) & 600,000 \\
\hline Fixed charges on capital ( $15 \%$ of capital) & $3,600,000$ \\
\hline Differential indirect expense & $4,400,000$ \\
\hline Differcntial manufacturing cost & $\$ 8,100,000$ \\
\hline
\end{tabular}

Other things being equal, the break-even condition at plant level will occur when the annual cost of makeup sorbent for the moving-bed system exceeds that for the reference system by $\$ 8,100,000$. Assuming annual 
replacement of the fixed-bed sorbent $(3,200,000 \mathrm{1b})$ and a sorbent . cost of $50 \mathrm{c}$ per $1 \mathrm{~b}$, the break-even consumption of sorbent in the moving-bed system is $19,400,000 \mathrm{lb} / \mathrm{yr}$.

In the moving-bed system, the sorbent is recycled at a $372,000-$ $\mathrm{lb} / \mathrm{hr}$ rate, and the cycle time is $3.5 \mathrm{hr}$, so that there will be 2300 cycles per year. At $19,400,0001 \mathrm{~b} / \mathrm{yr}$, the sorbent consumption is 8440 1b per cycle, which is equivalent to $0.65 \%$ of the sorbent inventory per cycle. The break-even consumptions at various assumed sorbent costs are tabulated as follows:

$\begin{array}{ccc}\begin{array}{c}\text { Sorbent cost } \\ (\$ / 1 b)\end{array} & \begin{array}{c}\text { Makeup sorbent } \\ (1 \mathrm{~b} \text { per cycle })\end{array} & \begin{array}{c}\text { Sorbent consumption } \\ (\% \text { per cycle })\end{array} \\ 0.2 & 19,000 & 1.46 \\ 0.5 & 8,440 & 0.65 \\ 1.0 & 4,910 & 0.38 \\ 1.5 & 3,740 & 0.29 \\ 2.0 & 3,150 & 0.24\end{array}$

\subsection{Comparison of Estimated Costs}

Estimates for the complete facilities shown on Figs. 1 and 2, which correspond to the differential estimates of Sects. 7.1 and 7.2, are tabulated as follows:

Fixed bed Moving bed Differentials

$\begin{array}{lcccc} & & & \text { Absolute } & \% \\ \text { Fixed capital, \$ } & 78,000,000 & 54,000,000 & 24,000,000 & 31 \\ \text { Ex́rport energy, MM Btu per hr } & 130 & 250 & 120 & 92 \\ \text { Operating cost, \$ per yr } & 16,800,000 & 8,700,000 & 8,100,000 & 48\end{array}$


A large energy loss in the fixed-bed system is associated with gas pressure drop in the absorbers. How the energy loss should be treated depends on how the gass will be used. For this estimate it is assumed that the gas will be used in a combined-cycle power plant, and the energy loss is equivalent to the power that could be produced in an expander operating with the same pressure drop. This amounts to about 10,000 horsepower, or $100 \mathrm{MM} \mathrm{Btu} / \mathrm{hr}$.

\section{REFERENCES}

1. C. H. Jones and J. M. Donohue, Comparative Evaluation of High and Low Temperature Gas Cleaning for Coal Gasification - Combined Cycle Power Plants, Stone and Webster Engineering Corp., Process Industries Group, One Penn Plaza, New York, N.Y., for EPRI, EPRI AF-416 (April 1977).

2. United States Steel Corporation, The Making, Shaping, and Treating of Stee1, 9th Edition, 1971.

3. D. F. Ciliberti, "Heat and Mass Balances for an Intermediate Temperature Iron Oxide Sulfur Removal System," Westinghouse Electr1c Corporation, Kesearch Memo 75-8E3-PDUPS-MI, Aug. 26, 1975.

4. F. A. Zenz and D. F. Othmer, Fluidization and Fluid-Particle Systems, Reinhold, New York, 1960.

5. Gordon L. Wade, "Performance and Modeling of Moving Granular Bed Filters," EPA/ERDA Symposium on High Temperature/Pressure Particulate Control, Washington, D.C. (Sept. 20, 1977).

6. W. L. Farrior, Jr., A. M. Poston, Jr., and E. C. O1daker, "Regenerable Iron Oxide-Silica Sorbents for the Removal of $\mathrm{H}_{2} \mathrm{~S}$ from Hot Producer Gas," presented at the Fourth Energy Resources Conference, University of Kentucky, Lexington, Ky., Jan. 6-7, 1976.

7. A. C. Bureau and M. J. F. Olden, "The Operation of the Frodingham Desulfurizing Plant at Exeter," Chem. Eng. (London), pp. CE55-62 (March, 1967).

8. G. L. Wade, "Particulate Removal from Hot Combustion Gases," Combustion Power Company, presented at the Fourth International Conference on Fluidized-Bed Combustion, December 1975. 
9. E. C. Oldaker and D. W. Gillmore, "Hot Gas Cleanup Process for Removing $\mathrm{H}_{2} \mathrm{~S}$ from Low-Btu Gases Using Iron Oxide Absorbents," 172nd National Meeting, American Chemical Society, San Francisco, CA., August 29-September 3, 1976, Division of Fuel Chemistry Preprints Vol. 21, No. 4, pp. 79-90.

10. J. T. Schrodt and 0. J. Hahn, Hot Fuel Gas Desulfurization, University of Kentucky, IMMR 15-PD11-76 (May 1976).

11. Air Products and Chemicals, Inc., Desulfurization of Low-Btu Producar Gas, ERDA/FE Coal Gasification Quarterly Report, January-March 1976.

12. E. C. O1daker, MERC, to M. S. Edwards, ORNL, personal communication, Septemher 6, 1977.

13. K. M. Guthrie, Process P1ant Estimating, Evaluation and Control, Craftsman, Solana Beach, Calif., 1974. 
ORNL/TM-6223

\section{INTERNAL DISTRIBUTION}

$\begin{aligned} \text { 1. } & \text { H. D. Cochran, Jr. } \\ \text { 2. } & \text { O. L. Culberson } \\ 3 . & \text { M. S. Edwards } \\ \text { 4. } & \text { D. E. Ferguson } \\ \text { 5. } & \text { J. F. Fisher } \\ 6-8 . & \text { W. R. Gambill } \\ 9-11 . & \text { R. W. Glass } \\ 12 . & \text { J. R. Hightower, Jr. } \\ 13 . & \text { J. M. Holmes } \\ \text { 14. } & \text { J. K. Huffstetler } \\ 15 . & \text { J. E. Jones } \\ \text { 16-19. } & \text { L. E. McNeese } \\ 20 . & \text { J. R. McWherter } \\ 21 . & \text { J. P. Meyer } \\ 22 . & \text { B. Niemann } \\ 23 . & \text { G. R. Peterson } \\ 24 . & \text { T. W. Picke1 } \\ 25 . & \text { H. Postma } \\ 26 . & \text { W. R. Reed }\end{aligned}$

27. M. W. Rosenthal

28. R. Salmon

29. C. D. Scott

30. M. Siman-Tov

31. S. P. N. Singh

32. D. B. Trauger

33. W. C. U1rich

34. R. G. Wymer

35. G. R. Choppin (Consultant)

36. L. J. Colby, Jr. (Consultant)

37. E. L. Gaden, Jr. (Consultant

38. L. E. Swabb (Consultant)

39. K. D. Timmerhaus (Consultant)

40. ORNL Patent Section

41. Lab Records RC

42-43. Lab Records

44-45. Central Research Library

46. Document Reference Section

EXTERNAL DISTRIBUTION

Department of Energy, Fossil Energy, 400 First Street, Washing ton, D.C. 20545

47. J. D. Batchelor (Room 508)

48. E. L. Clark (Room 407)

49. N. P. Cochran (Room 501)

50. D. Garrett (Room 504)

51. H. T. Jones (Room 501)

52. T. K. Lau (Koom 504)

53. J. J. Powell (Room 504)

54. H. L. Weisenfeld (Room 501)

Department of Energy, Fossil Energy, 20 Massachusetts Avenue, N.W., Washington, D.C. 20545

55. J. A. Belding (Room 2220)

56. C. W. DiBella (Room 4217)

57. H. Frankel. (Rocm 4203)

58. L. M. Joseph (Room 4128)

59. L. Kindley (Room 4206)

60. T. B. Simpson (Room $4128 / R B$ ) 
Department of Energy, Division of Environmental Control, Mail Stop E-201, Washington, D.C. 20545

61. N. F. Barr

62. R. M. Jimeson

63. W. E. Mott

64. R. W. Wood

65. F. E. Witmer

66-68. R. H. Lamb (Consultant), 538 West Hunt Road, Alcoa, Tennessee 37701

69-71. L. Seglin (Consultant), Econergy Associates, 799 Broadway, New York, New York 10003

72. F. L. Culler, Electric Power Research Institute, 3412 Hillview Avenue, Palo Alto, Calitornia y4303

73. Theresa Wiley, Institute Librarian, University of Kentucky, Institute for Mining and Materials Késearch, 213 brädiey Háll, Lexington, Kentucky 40506

74. Robert Rabin, National Science Foundation, 1800 G. Street, NW, Washington, D.C. 20550

75. Charles B. Sedman, U.S. Environmental Protection Agency, Research Triangle Park, North Carolina 27711

76-81. DOE Pittsburgh Energy Research Center, Department of Energy Administration, Attention: Director for J. P. Barreca, 4800 Forbes Avenue, Pittsburgh, Pennsylvania 15213

82-87. The Director, Morgantown Energy Research Center, P.0. Box 800, Morgantown, West Virginia 26506

88. Department of Energy, Oak Ridge Operations, Research and Technical Support Division

89-115. Technical Information Center, Oak Ridge, Tenn. 37830 